\title{
Okul Öncesi Öğretmen Adaylarının Toplumsal Cinsiyet Rollerine İlișkin Tutumlarının Belirlenmesi
}

\author{
Nudar Yurtsever ${ }^{1}$, \& D. Esra Angın ${ }^{2}$
}

\begin{abstract}
Özet: Toplumsal cinsiyet rollerine ilişkin tutumların oluşmasında toplumsallaşma süreci etkilidir. Bu süreçte bireyin çevresi önemli bir değişkendir. Toplumsallaşma sürecinde çocuklar ile etkileşim kuracak olmaları açısından okul öncesi öğretmen adaylarının nasıl bir tutum belirledikleri önemlidir. Bu önem doğrultusunda çalışma okul öncesi öğretmen adaylarının toplumsal cinsiyet rollerine ilişkin tutumlarını belirlemek amacıyla gerçekleştirilmiştir. Tarama modeli kullanılarak yapılan bu çalışma Aydın Adnan Menderes Üniversitesi Eğitim Fakültesi Okul Öncesi Eğitimi Anabilim Dalı’nda öğrenim görmekte olan tabakalı amaçsal örnekleme yöntemiyle seçilmiş birinci ve dördüncü sınıfta öğrenim görmekte olan toplam 165 öğretmen adayı ile gerçekleştirilmiştir. Çalışmada veri toplama aracı olarak "Sosyodemografik Özellikler Formu" ve Zeyneloğlu (2008) tarafından geliştirilmiş olan "Toplumsal Cinsiyet Rolleri Tutum Ölçeği” kullanılmıştır. Verilerin analizinde tanımlayıcı istatistikler, Mann- Whitney U ve Kruskal- Wallis testleri kullanılmıştır. Araştırma bulguları incelendiğinde, öğretmen adaylarının toplumsal cinsiyet rollerine ilişkin tutumlarında üniversiteye başlayıncaya kadar ikamet ettiği yer ve baba eğitim durumu değişkenleri açısından fark yokken, cinsiyet, sınıf ve anne eğitim durumu değişkenleri açısından anlamlı fark olduğu tespit edilmiştir.
\end{abstract}

Anahtar Kelimeler: Toplumsal Cinsiyet, Toplumsal Cinsiyet Rolü, Öğretmen Adayı

Geliş Tarihi: 13.12.2019 - Kabul Tarihi: 25.06.2020 - Yayın Tarihi: 29.06.2020

DOI: $10.29329 / \mathrm{mjer} .2020 .258 .18$

\section{Determination of Preschool Teacher Candidates' Attitudes Towards Gender Roles}

Abstract: The socialization process is effective in forming attitudes towards gender roles. In this process, the environment of the individual is an important variable. Since they interact with the children, it is essential to know the attitude preschool teacher candidates have towards the children. In line with this point, the study aimed to determine the attitudes of preschool teacher candidates toward gender roles. The sample consisted of 165 first and fourth-grade teacher candidates selected by stratified purposive sampling among the students at Aydın Adnan Menderes University Faculty of Education, Preschool Education Department. The study was carried out by the scanning method. As the data collection tool, the "Gender Role Attitude Scale," developed by Zeyneloğlu (2008), was used. In order to analyze the data, Kolmogorov-Smirnov tests, descriptive statistics, Mann-Whitney

\footnotetext{
${ }^{1}$ Nudar Yurtsever, Okul Öncesi Eğitimi, Aydın Adnan Menderes Üniversitesi Sosyal Bilimler Enstitüsü, ORCID: 00000003-0605-4432

${ }^{2}$ D. Esra Angın, Assist. Prof. Dr., Okul Öncesi Eğitimi Anabilim Dalı, Aydın Adnan Menderes Üniversitesi, ORCID: 00000001-6601-4892
}

Correspondence: senozgur@yahoo.com 
U, and Kruskal-Wallis tests were used. The results showed that the attitudes of the preschool teacher candidates toward gender roles were not statistically significant concerning the sizes of hometown and educational level of the father, while there was a significant difference in the attitudes toward gender roles concerning gender, class, and mother's education status.

Keywords: Gender, Gender Roles, Teacher Candidate

\section{GİRIŞ}

Tıp bilimlerindeki cinsiyet kavramı, biyolojide 'eşey' ya da 'cinslik' olarak adlandırılır. Bu yönüyle cinsiyet bireyin doğuştan getirdiği değişmeyen ve her yerde aynı olan bir özelliğidir (Adaçay, 2014; Akın ve Demirel, 2003; Bem, 1981; Torgrimson ve Minson, 2005). Toplumdaki bireylerin kadın ya da erkek olmanın biyolojik özellikleri dışında, yaşadığı toplumun ahlak, din, kültür, gelenek gibi pek çok değer yargı çerçevesinde şekillenen toplumsal bir anlamı da vardır. Bu toplumsal anlam toplumsal cinsiyet olarak karşımıza çıkar. Bir başka deyişle toplumsal cinsiyet bireyin biyolojik cinsiyetinin yanında yaşadığı toplum tarafından oluşturulmuş, şekillendirilmiş hatta dayatılmış özellik ve beklentilerdir (Adaçay, 2014; Torgrimson ve Minson, 2005).

Toplumsal cinsiyet çalışmaları cinsiyete bakış açıları dikkate alınarak birkaç aşamadan geçmiştir. Çalışmalar başlangıcında önce cinsiyetler arasındaki farklılıklar vurgulanmış, daha sonra bu cinsiyet farklılıklarının toplumsallaşma sürecinde öğretildiği, öğrenildiğine dikkat çekilmiştir. En son aşamada ise toplumsal cinsiyetin tüm sosyal sistemlerde önemli rolü keşfedilmiştir (Ecevit, 2016). Toplumsal cinsiyet çalışmalarına bakıldığında doğacı görüşe sahip olanlar toplumsal iş bölümünün tarihsel olarak kadın ve erkek arasındaki fiziksel ve biyolojik farklılıklardan kaynaklandığını ifade etmişlerdir. Doğacı görüşe göre erkekler kadınlardan fiziksel olarak daha üstün olduğu için savaşçı, avcı gibi dışa dönük özellikleri almışlardır. Kadınların ise hem fiziksel olarak zayıf olduğu hem de doğurganlıkları sebebiyle haneye bağımlı olduklarını ifade etmişlerdir. Bu durum toplumsal iş bölümünde erkeklerin hane dışında, kadınların ise hane içindeki işleri üstlenmesiyle sonuçlandığını savunmuşlardır. Gelişmeci görüşe sahip olanlar ise teknolojinin ilerlediği günümüz dünyasında kas gücü kullanılarak yapılan işlerin azalmasıyla erkeklerin yaptığı işler ile kadınların yaptığı işler arasında farkın azaldığını bu nedenle cinsiyet ile toplumsal cinsiyet arasındaki ilişkinin zayıfladığını savunmuşlardır (Ecevit, 2016).

Toplumsal cinsiyet çalışmalarının geçirdiği aşamalar yanında, toplumsal cinsiyeti açıklayan teoriler de bulunmaktadır. Bunlardan bazıları psikanalitik kuram, bilişsel gelişim kuramı, sosyal öğrenme kuramı, toplumsal cinsiyet şeması kuramıdır. Psikanalitik kuram kadın ve erkek arasındaki farklılıkları penisin yarattığını ifade etmektedir. Çocukların cinsiyet farklılıklarını anlamaya başladığı 3-5 yaş arası dönemde erkek çocukların kız çocuklarının penise sahip olmadıklarını görmekte ve cinsel ilgilerinin annelerine yönlendirilirse babalarının onları cezalandıracağından korkmaktadır. Kız çocukları ise benzer bir biçimde babaya ilgi duyma ve anne tarafından cezalandırılma korkusu biçiminde yaşamaktadırlar. Ödipal döneme gelindiğinde ise artık erkekler korktukları için babalarıyla 
olan çekişmelerinden vazgeçer ve babalarıyla özdeşleşir. Babayla özdeşleşerek erkeksi hale gelen çocuk sembolik olarak anne yerine cinsel ilişkiler yaşayabilmek için heteroseksüel olur (Kimmel, 2000). Freud'un kuramına göre; kız çocukları annelerinin penisi olmaması sebebiyle anneleriyle özdeşleşmeye zorunlu olmadığı için süperegoları erkek çocuklarınki kadar gelişmemiştir ve hem cinsel hem ahlaki olarak erkekler kadar üstün değildir (Can, 2013; Dökmen, 2015; Zeyneloğlu, 2008).

Kohlberg'e ait bilişsel öğrenme kuramında ise Kohlberg Piagetden etkilenmiştir. Bilişsel gelişim kuramına göre çocuklar cinsiyet etiketleme döneminde (2-3,5 yaş) çocuklar cinsiyetinin farkındadır fakat değişmezliğini henüz kavrayamamıştır. Cinsiyetin kararlılı̆̆ 1 döneminde $(3,5-4,5$ yaş) çocuklar cinsiyetin sabit ve değişmez olduğunu anlamaya başlamış yine de fiziksel özelliklerinden etkilenmektedir. Bir erkek çocuğu bu yaşta saçlarını uzattığında kız olacağını düşünebilir. Cinsiyetin değişmezliği döneminde çocuklar artık cinsiyetin fiziksel görünümden bağımsız olarak var olduğunu kavramışlardır ve cinsiyetleri ile tutarlı olarak davranış sergilerler. $\mathrm{Bu}$ davranışları ise ödüllendirildikleri için değil cinsiyetleriyle tutarlı olduğu için gerçekleştirdiği belirtilir (Dökmen, 2015; Helgeson, 2012; Zeyneloğlu, 2008). Davranışlar cinsel kimliğe dayandığı için çocuklar cinsiyet algısını bilişsel bir filtreden geçirerek çocuklar aktif olarak cinsiyet anlayışı geliştirir ve yine aktif bir şekilde kendilerini toplumsallaştırır (Kimmel, 2000; Ryle, 2012).

Sosyal öğrenme kuramında çocuk cinsiyete uygun bir davranış sergilediği zaman ödüllendirilirse bu davranışa dönüşürken ödüllendirilmeyen davranış ise zamanla kaybolur. Örneğin saldırgan tavırlar sergileyen erkek çocuğa 'aferin aslanıma' gibi sözler söylenerek davranışı pekiştirilirken; aslanın dişisi de erkeği de olmasına rağmen, kız çocuklarda bu davranış pekiştirilmez. Temizlik için annesine yardım etmeye gelen bir erkek çocuk da aynı şekilde annesi tarafından uzaklaştırılırken; kumandayı, TV'yi tamir eden babasına yardım etmek isteyen kız çocuğa da ona uygun iş olmadığı söylenerek uzaklaştırılır (Ryle, 2012). Model alma ve taklitte ise gözlenen figürler model alınarak bunların davranışları tekrar edilir. Cinsiyet rollerinin kazanımlarında da erkek çocuklar babalarını ve diğer erkek figürleri model alıp taklit ederken; kız çocukları ise annelerini ve diğer kadın figürlerini gözlemleyerek taklit ederler (Doyle ve Paludi, 1998). Bu kuram anne-babalar, öğretmenler, yakın çevre ve kitle iletişim araçlarının cinsiyet rollerinin öğrenilmesinde önemli rolü olduğunu belirtmektedir (Adaçay, 2014; Dökmen, 2015; Zeyneloğlu, 2008).

Bem'in ise bilişsel gelişim ve sosyal öğrenme kuramlarının temel görüşlerini birleştirerek toplumsal cinsiyet şeması kuramını ileri sürmüştür. Bilişsel gelişim kuramına benzemesinin sebebi çocuğun cinsiyetleri tipleştirmesinin kültürün kadınlık ve erkeklik tanımlarına göre algılamaya ve kodlamaya hazır oluşundan kaynaklandığını kabul etmesidir. Cinsiyet şeması temelinde bilgi işlemenin toplumun cinsiyet ayrımcı uygulamalarından kaynaklandığını ileri sürmesi bakımından sosyal öğrenme kuramına benzer. Sosyal öğrenme kuramına benzemesinin sebebi ise cinsiyeti ayrıştırma sürecinin öğrenilmiş olduğunu kabul etmesinden, bunun değiştirilebilen bir süreç olmasıdır. Örneğin çocuklar kibar, sakin gibi özellikleri kadınsı kategorisinde atılgan, bağımsız, kendine güvenen 
gibi özellikleri erkeksi kategorisine sokarak işler. Bundan sonra çocukların zihinlerinde iki farklı cinsiyet şeması yaratılmış yani toplumsal cinsiyeti edinmişlerdir (Adaçay, 2014; Dökmen, 2015).

Yukarıda açıklanmaya çalışılan kuramlar da değerlendirildiğinde toplumsal cinsiyete ilişkin tutumları etkileyen faktörler bulunduğu görülmektedir. $\mathrm{Bu}$ faktörlerin birisi aile karşımıza çıkmaktadır. Çocuğun dünya ile olan ilişkisi ilk olarak aile aracılığıyla olur. Ailenin çocuğun odasında veya kıyafetlerinde seçtiği renkler (kız bebekleri için pembe, erkek bebekleri için mavi) çocuklarını etiketlemektedir. Çocuklar bu sayede hangi renklerin kendi cinsiyetine uygun olduğunu öğrenmektedirler (Pomerleau, Bolduc, Malcuit ve Cossette, 1990). Erkek çocuklarına güç anlamı içeren isimleri koyarken (Yiğit, Aslan, Kral vb.); kız çocuklarına güzellik, incelik, saflık içeren isimleri (Güzel, Gül, Sevgi, Bahar, Duru vb.) vererek yaşamın ilk basamağında bile çocukların toplumsallaşmasını cinselliğe bağlamış olurlar. Bu gibi davranışlar ile toplumsal cinsiyet rollerine ilişkin inançlarını çocuklarına aktarmış olmaktadırlar. Ailelerin çocuklarıyla iletişimlerine de açık ya da örtük bir şekilde yansımaktadır. Rekabet etmek, galibiyet kazanmak, bağımsız hareket etmek gibi davranışlar sergilemede erkek çocuklarını kız çocuklarına göre daha fazla teşvik etmekte bu alanda görevler vermektedir. Ailelerinin bunun gibi davranışları çocuğun toplumsal cinsiyet rollerine ilişkin tutumlarının geleneksel mi eşitlikçi mi olacağını belirlemekte önemli olmaktadır (Seçgin ve Tural, 2011; Zeyneloğlu, 2008). Kardeş ve arkadaş grupları da büyük kardeşin davranışlarının ve arkadaşların davranışlarından etkilenerek ya da "kız oyunu" ve "erkek oyunu" olarak gördükleri davranışlar toplumsal cinsiyet rollerinin kazanılmasında etkili olan önemli etkenlerden biridir (Dökmen, 2015; Zeyneloğlu, 2008).

Bir diğer etken olarak da çocuk kitapları ve kitle iletişim araçları incelendiğinde kadınların edilgen, çoğunlukla ev içinde olan; erkeklerin ise savaşçı, kahraman mücadeleci, kararı veren ve sonunda hep kazanan olduğu görülmektedir. Yine aynı şekilde bazı meslekler kadınlara atfedilirken (öğretmen, aşçı, terzi vb.); bazı mesleklerin (mimar, şoför, gazeteci, avukat, pilot) erkeklere atfedildiği görülmektedir (Çatalcalı-Soyer, 2009; Gündüz- Şentürk, 2015; Köseler, 2009; Oğuz-Rollas, 2017). Gündüz-Kalan'ın (2010) Kinder reklamlarını incelediği çalışmada ve Kalaycı'nın (2015) Pepee çizgi filmini incelediği çalışmada kahramanların yaptığı davranışların iki cinsiyet tarafından da yapılabilecek işler olmasına rağmen cinsiyet kalıpyargılarını yansıtan rol ve davranış biçimleri içerdikleri ifade edilmiştir.

Foster (1990) ve Ferguson'da (1998) öğretmenlerin cinsiyete ilişkin kültürel varsayımlardan etkilendiğini, kasıtlı olsun veya olmasın bu varsayımları sınıf uygulamalarında sürdürdüklerini belirtmiş̧lerdir (Akt. Stoll, 2011). Öğretmenlerin matematik, fen gibi derslerde erkeklerin daha başarılı olduğunu düşünmeleri, kız çocuklarına başarmak için çok çalışması gerektiği erkek çocuklara ise biraz daha çalışırsan başaracaksın mesajı veren davranışları olduğu görülmektedir. Bu durum bir okul öncesi sınıfında öğretmenin çocuklara "Kızların içeride oynamayı tercih edeceklerini biliyorum." söylemiyle örneklendirilebilir (Wolter, Braun ve Hannover, 2015). Yapılan araştırmalarda okul araç 
gereçlerinden olan ders kitaplarına da bu durumun yansıdığı görülmektedir. Kitaplarda kullanılan dilin eril bir dil olduğu, erkek çocukların resimlerine kız çocuklarına oranla daha çok yer verildiği ve kız çocuklarının genellikle hane içinde olduğu görülmüş̧ür. Erkek çocuklar daha çok yalnız ve tek başına bir faaliyet içindeyken; kız çocukların diğer çocuklarla ya da yetişkin bir kadın figürü ile birlikte gösterildiği ifade edilmiştir (Asan, 2010; Gunderson, Ramirez, Levine ve Beilock, 2012; Zeyneloğlu, 2008).

Cinsiyet rolleri ile ilgili kalıpyargılar çocukların cinsel kimlikleri benimsemelerinde, duygularını düşüncelerini ve davranışlarını cinsel kimlikleri ile uyumlu hale getirmelerinde ve cinsiyet rollerinin benimsenmesinde etkilidir (Ocak-Karabay, Güzeldere-Aydın, Tunç ve Kanbur, 2019). Cinsiyet rollerine ilişkin tutumların oluşmasında toplumsallaşma önemlidir. Toplumsallaşma sürecinde bireyin yakın çevresi, izledikleri, okudukları, öğrenim yaşantısı gibi değişkenler etkili olmaktadır. Bireyin toplumsallaşma sürecinde öğretmenlerin önemli rolünden, eğitimde toplumsal cinsiyet eşitliğini teşvik etmenin ve eğitim yoluyla bunun sağlanmasının öneminden yola çıkarak (Ergün, 1994; Lahelma, 2006; Öztürk, 1993); bu çalışmada, okul öncesi öğretmen adaylarının toplumsal cinsiyet rollerine ilişkin tutumlarının çeşitli değişkenler açısından incelenmesi amaçlanmıştır.

\section{YÖNTEM}

\subsection{Araştırma Modeli}

Çalışma nicel araştırma yöntemlerinden tarama modeline göre desenlenmiştir. Bir duruma ilişkin katılımcıların görüşlerinin ya da ilgi, beceri, yetenek, tutum gibi özelliklerini belirlemek için, görece diğer araştırmalardan daha büyük örneklemler üzerinde yapılan araştırmalara tarama araştırmaları denir (Büyüköztürk, vd., 2016).

\section{2. Çalışma grubu}

Çalışma grubunu, Aydın Adnan Menderes Üniversitesi Eğitim Fakültesi Okul Öncesi Eğitimi Anabilim Dalı'nda öğrenim gören amaçsal örnekleme yöntemiyle seçilen 125'i kadın, 40'1 erkek birinci ve dördüncü sınıf 165 okul öncesi eğitimi öğretmen adayı oluşturmaktadır. Anne eğitim durumu ve baba eğitim durumu değişkenleri incelendiğinde, ilkokul mezunlarının çoğunlukta olduğu görülmektedir. Üniversiteye başlayıncaya kadar ikamet ettiği yer özelliklerine bakıldığında ise, il ve ilçenin köye göre çoğunlukta olduğu, sınıf düzeyine bakıldığında ise birinci sınıfa devam eden 78 , dördüncü sınıfa devam eden 87 kişi olduğu görülmektedir. Demografik bilgilere ilişkin bilgiler Tablo1'de verilmiştir. 
Tablo1. Çalışmaya Katılan Öğretmen Adaylarına İlişkin Demografik Bilgiler

\begin{tabular}{|c|c|c|c|c|c|c|c|}
\hline & & $\mathbf{n}$ & $\%$ & & & $\mathbf{n}$ & $\%$ \\
\hline \multirow[b]{2}{*}{ Cinsiyet } & Kadın & 125 & 75,8 & \multirow{4}{*}{$\begin{array}{l}\text { Üniversiteye } \\
\text { Başlayincaya } \\
\text { Kadar İkamet } \\
\text { Ettiği Yer }\end{array}$} & İl & 76 & 46,1 \\
\hline & Erkek & 40 & 24,2 & & İlçe & 73 & 44,2 \\
\hline \multirow[b]{2}{*}{ Sinıf Düzeyi } & 1.sinif & 78 & 47,3 & & Köy & 16 & 9,7 \\
\hline & 4.sinif & 87 & 52,7 & & & & \\
\hline \multirow{6}{*}{$\begin{array}{l}\text { Anne Eğitim } \\
\text { Durumu }\end{array}$} & Okur yazar değil & 27 & 16,4 & \multirow{6}{*}{$\begin{array}{l}\text { Baba Eğitim } \\
\text { Durumu }\end{array}$} & Okur yazar değil & 7 & 4,2 \\
\hline & Okur yazar & 16 & 9,7 & & Okur yazar & 13 & 7,9 \\
\hline & İlkokul & 77 & 46,7 & & İlkokul & 52 & 31,5 \\
\hline & Ortaokul & 18 & 10,9 & & Ortaokul & 40 & 24,2 \\
\hline & Lise & 19 & 11,5 & & Lise & 32 & 19,4 \\
\hline & $\begin{array}{l}\text { Üniversite/ } \\
\text { Lisansüstü }\end{array}$ & 8 & 4,8 & & $\begin{array}{l}\text { Üniversite/ } \\
\text { Lisansüstü }\end{array}$ & 21 & 12,7 \\
\hline
\end{tabular}

\subsection{Veri Toplama Araçları}

$\mathrm{Bu}$ çalışmada öğretmen adaylarının demografik özelliklerini belirlemek amacıyla araştırmacılar tarafından geliştirilen 'Sosyodemografik Özellikler Formu', toplumsal cinsiyet rollerine ilişkin tutumlarını belirlemek amacıyla ise Zeyneloğlu (2008) tarafindan geliştirilen 38 maddeden oluşan 5'li likert tipi ‘Toplumsal Cinsiyet Rolleri Tutum Ölçeği (TCRTÖ)' kullanılmıştır. Ölçekten alınan puanın 95 puanın üzerinde olması kişinin eşitlikçi tutuma sahip olduğunu göstermektedir. Toplumsal Cinsiyet Rolleri Tutum Ölçeğinin Cronbach Alfa Güvenirlik Katsayısı 38 madde için .92 dir (Zeyneloğlu ve Terzioğlu, 2011).

\subsection{Verilerin Analizi}

Çalışmadan elde edilen veriler uygun bilgisayar programında değerlendirilmiştir. Çalışmaya katılan öğretmen adaylarının demografik özelliklerine ilişkin verilerin analizinde tanımlayıcı istatistiklerden yararlanılmıştır. Aynı zamanda tutum puanlarının normal dağılım gösterip göstermediği Kolmogorov- Smirnov ile analiz edilmiş verilerin normal dağ 1 llım göstermediği görülmüştür $(\mathrm{p}<0,05)$. $\mathrm{Bu}$ nedenle cinsiyete ilişkin tutumların çeşitli değişkenler açısından incelenmesinde Mann- Whitney U ve Kruskal- Wallis testleri kullanılmıştır.

\section{BULGULAR}

Tablo2. Toplumsal Cinsiyet Rolleri Tutum Ölçeği’nden Alınan Toplam Puanlara İlişkin Tanımlayıcı İstatistikler

\begin{tabular}{llllllll}
\hline Sinıf & N & $\%$ & $\overline{\mathrm{x}}$ & Medyan & Mod & $\begin{array}{l}\text { En Düşük } \\
\text { Değer }\end{array}$ & $\begin{array}{l}\text { En Yüksek } \\
\text { Değer }\end{array}$ \\
\hline Birinci Sinıf & 78 & 47,3 & 159,17 & 163 & 154 & 117 & 190 \\
\hline Dördüncü Sinıf & 87 & 52,7 & 170,01 & 175 & 178 & 126 & 190 \\
\hline Toplam & 165 & 100 & & & & & \\
\hline
\end{tabular}

Tablo 2 incelendiğinde; çalışmaya katılan birinci ve dördüncü sınıfa devam eden öğretmen adaylarının TCRTÖ' den aldıkları toplam puanların 95'in üzerinde olduğu görülmektedir. 
Tablo 3. Toplumsal Cinsiyet Rollerine İlişkin Tutumların Cinsiyet Değişkeni Açısından Mann Whitney-U Testi Analizi Sonuçları

\begin{tabular}{lllllllll}
\hline Grup & $\mathrm{n}$ & $\overline{\mathrm{x}}$ & Ss & $\begin{array}{l}\text { Sira } \\
\text { Ortalaması }\end{array}$ & Sira Toplamı & U değeri & $\begin{array}{l}\mathrm{Z} \\
\text { değeri }\end{array}$ & $\begin{array}{l}\mathrm{p} \\
\text { değeri }\end{array}$ \\
\hline Kadın & 125 & 169,147 & 15,976 & 92,31 & 11538,50 & 1336,500 & $-4,425$ &, 000 \\
& & & & & & & & \\
\hline Erkek & 40 & 151,5982 & 21,845 & 53,91 & 2156,50 & & & \\
\hline Toplam & 165 & & & & & & & \\
\hline
\end{tabular}

Tablo 3'e göre; öğretmen adaylarının cinsiyet değişkenleri açısından TCRTÖ puanlarında farklılık olup olmadığını ortaya koymak için yapılan Mann-Whitney U testinin sonucuna göre, öğretmen adaylarının TCRTÖ puanları sıra ortalamaları arasında kadın öğrencilerin lehine istatistiksel olarak anlamlı bir fark bulunmuştur $(\mathrm{z}=-4,425, \mathrm{p}<0,05)$. Buradan kadın öğrencilerin erkeklere göre daha yüksek toplumsal cinsiyet rollerine ilişkin tutumlara sahip olduğu anlaşılmaktadır.

Tablo4: Toplumsal Cinsiyet Rollerine İlişkin Tutumların Sınıf Değişkeni Açısından Mann Whitney-U Testi Analizi Sonuçları

\begin{tabular}{|c|c|c|c|c|c|c|c|c|}
\hline Grup & $\mathrm{n}$ & $\overline{\mathrm{x}}$ & Ss & $\begin{array}{l}\text { Sira } \\
\text { Ortalamas1 }\end{array}$ & Sira Toplamı & U değeri & $\begin{array}{l}Z \\
\text { değeri }\end{array}$ & $\begin{array}{l}\mathrm{p} \\
\text { değeri }\end{array}$ \\
\hline $\begin{array}{l}\text { Birinci } \\
\text { Sinıf }\end{array}$ & 78 & 159,1786 & 19,789 & 68,37 & 5332,50 & \multirow[t]{2}{*}{2251,500} & \multirow[t]{2}{*}{$-3,727$} &, 000 \\
\hline $\begin{array}{l}\text { Dördüncü } \\
\text { Sinıf }\end{array}$ & 86 & 170,0154 & 16,916 & 96,12 & 8362,50 & & & \\
\hline Toplam & 165 & & & & & & & \\
\hline
\end{tabular}

Tablo 4'de öğretmen adaylarının sınıf değişkeni açısından TCRTÖ puanları arasında farklılık olup olmadığını ortaya koymak için yapılan Mann-Whitney U testinin sonucuna göre, birinci ve dördüncü sınıf öğretmen adaylarının TCRTÖ puanları sıra ortalamaları arasında dördüncü sınıf öğrencileri lehine anlamlı bir fark olduğu bulunmuştur $(z=-3,727, p<0,05)$. Buradan dördüncü sinıf öğrencilerin birinci sınıf öğrencilere göre daha yüksek toplumsal cinsiyet rollerine ilişkin tutumlara sahip olduğu anlaşılmaktadır.

Tablo5. Toplumsal Cinsiyet Rollerine İlişkin Tutumların Üniversiteye Başlayıncaya Kadar İkamet Ettiği Yer Değişkeni Açısından Kruskal Wallis Testi Sonuçları

\begin{tabular}{|c|c|c|c|c|c|}
\hline Grup & $\mathrm{N}$ & $\begin{array}{l}\text { Sira } \\
\text { Ortalaması }\end{array}$ & $\mathrm{Sd}$ & $X^{2}$ & $\mathrm{p}$ \\
\hline İl & 76 & 90,13 & 2 & 3,909 &, 142 \\
\hline İlçe & 73 & 79,00 & & & \\
\hline Köy & 16 & 67,41 & & & \\
\hline Toplam & 165 & & & & \\
\hline
\end{tabular}


Öğretmen adaylarının TCRTÖ puanlarında üniversite eğitimine başlayıncaya kadar ikamet ettiği yer değişkenine göre fark olup olmadığını görmek için yapılan Kruskal-Wallis testine göre, grupların TCRTÖ puanları arasında anlamlı fark gözlenmemiştir $\left[X^{2}(2)=3,909, p>0,05\right]$.

Tablo6. Toplumsal Cinsiyet Rollerine İlişkin Tutumların Anne Eğitim Düzeyi Değişkeni Açısından Kruskal- Wallis Testi Analizi Sonuçları

\begin{tabular}{|c|c|c|c|c|c|c|}
\hline Grup & $\mathbf{n}$ & $\begin{array}{l}\text { Sira } \\
\text { Ortalaması }\end{array}$ & sd & $\mathrm{X}^{2}$ & $\mathbf{p}$ & Anlamlı Fark \\
\hline Okuryazar değil & 27 & 56,20 & 5 & 19,020 & ,002 & $\begin{array}{l}\text { Okuryazar değil- } \\
\text { İlkokul }\end{array}$ \\
\hline Okur yazar & 16 & 75,22 & & & & \\
\hline İlkokul & 77 & 89,53 & & & & Lise \\
\hline Ortaokul & 18 & 67,83 & & & & Okuryazar değil- \\
\hline Lise & 19 & 101,16 & & & & $\begin{array}{l}\text { Üniversite/Lisans } \\
\text { üstü }\end{array}$ \\
\hline $\begin{array}{l}\text { Üniversite } \\
\text { /Lisansüstü }\end{array}$ & 8 & 117,19 & & & & Ortaokul-Lise \\
\hline Toplam & 165 & & & & & $\begin{array}{l}\text { Ortaokul- } \\
\text { Üniversite/Lisans } \\
\text { üstü }\end{array}$ \\
\hline
\end{tabular}

Öğretmen adaylarının TCRTÖ puanlarının anne eğitim düzeyi değişkeni açısından fark olup olmadığını görmek için yapılan Kruskal-Wallis testine göre, grupların TCRTÖ puanları arasında anlamlı fark gözlenmiştir $\left[X^{2}(6)=19,020, p<0,05\right]$. Mann-Whitney $U$ testi ile yapılan çoklu karşılaştırmalar sonunda bu farkın, okuryazar değil ile ilkokul arasında, okuryazar değil ile lise arasında, okuryazar değil ile üniversite arasında, ortaokul ile lise arasında, ortaokul ile üniversite eğitim düzeyleri arasında olduğu belirlenmiştir.

Tablo7. Toplumsal Cinsiyet Rollerine İlişsin Tutumların Baba Eğitim Düzeyi Değişkeni Açısından Kruskal-Wallis Testi Analizi Sonuçları

\begin{tabular}{|c|c|c|c|c|c|}
\hline Grup & $\mathrm{n}$ & Sira Ortalaması & $\mathrm{sd}$ & $\mathrm{X}^{2}$ & $\mathrm{p}$ \\
\hline Okuryazar değil & 7 & 56,36 & 5 & 9,482 & ,091 \\
\hline Okur yazar & 13 & 67,19 & & & \\
\hline İlkokul & 52 & 82,38 & & & \\
\hline Ortaokul & 40 & 74,79 & & & \\
\hline Lise & 32 & 97,61 & & & \\
\hline Üniversite & 21 & 96,57 & & & \\
\hline Toplam & 165 & & & & \\
\hline
\end{tabular}

Öğretmen adaylarının TCRTÖ puanlarının baba eğitim düzeyi değişkeni açısından fark olup olmadığını görmek için yapılan Kruskal-Wallis testine göre, grupların TCRTÖ puanları arasında anlamlı fark gözlenmemiştir $\left[\mathrm{X}^{2}(6)=9,482, \mathrm{p}>0,05\right]$. 


\section{TARTIŞMA VE SONUÇ}

Bu çalışma ile okul öncesi öğretmen adaylarının toplumsal cinsiyet rollerine ilişkin tutumlarını belirlemek amaçlanmıştır. Bu amaca bağlı olarak öğretmen adaylarının toplumsal cinsiyet rollerine ilişkin tutumları cinsiyet, sınıf, üniversite eğitimine başlayıncaya kadar yaşadığı yerin gelişmişlik düzeyi, annenin eğitim düzeyi, babanın eğitim düzeyi gibi değişkenler açısından incelenmiştir.

Yapılan analizler sonucunda, tüm öğretmen adaylarının TCRTÖ' ye ilişkin puanlarının 95'in üzerinde olması sebebiyle adayların toplumsal cinsiyete ilişkin tutumlarının eşitlikçi olduğu belirlenmiştir. Öğretmen adaylarının toplumsal cinsiyet rollerine ilişkin tutumlarının eşitlikçi olması, toplumsallaşma sürecinde öğretmenlerin rolü düşünüldüğünde doğrudan ve sürekli etkileşim içinde oldukları çocukları toplumun bir üyesi olarak davranmaya hazırlamaları sebebiyle önemli bir durum olarak karşımıza çıkmaktadır (Bar-Tal ve Harel, 2002; Ergün, 1994; Öztürk, 1993).

Öğretmen adaylarının TCRTÖ puanları cinsiyet değişkeni açısından incelendiğinde; öğretmen adaylarının toplumsal cinsiyet rolleri tutumları sıra ortalamaları arasında kadın öğrencilerin lehine istatistiksel olarak anlamlı bir fark bulunmuştur. Bu sonuç toplumsal cinsiyet eşitsizliğinin genelde erkeğin yararına işlemesinden ve kadınların mağduriyetlerinden kaynaklı bilinçlenmesinden kaynaklı olabileceğini düşündürmektedir. Yapılan çalışmalarda da bu çalışmadan elde edilen bulguyu destekler nitelikte sonuçlara rastlanmıştır (Almutawa, 2005; Engin-Demir vd., 2016; Güzel, 2016; Öngen ve Aytaç, 2013; Seçgin ve Tural, 2011; Tatar ve Emmanuel, 2009; Vefikuluçay, Zeyneloğlu, Eroğlu ve Taşkın 2007; Zeyneloğlu, 2008). Shechter'da (2006), cinsiyet eşitliğinin eğitimde önemli bir konu olduğunu ve hem kadın hem de erkek bireyleri etkileyen bir sorun olduğunu ifade etmiştir. Aynı zamanda toplumdaki bireylerin cinsiyete ilişkin eşitsizliği açıkça tanımlayabildiklerinde cinsiyet eşitliğini içeren eğitim uygulamalarının oluşturulması yönünde ilerleme kaydedilebileceğini ortaya koymuştur.

Öğretmen adaylarının TCRTÖ puanları sınıf değişkenine göre incelendiğinde; birinci ve dördüncü sınıf öğretmen adaylarının toplumsal cinsiyet rolleri tutumları sıra ortalamaları arasında dördüncü sınıf öğrencileri lehine anlamlı bir fark olduğu bulunmuştur. Birinci ve dördüncü sınıf olmanın çalışmaya konu olan toplumsal cinsiyet rollerine ilişkin tutumlarının üzerinde anlamlı bir etkisinin olduğu söylenebilir. Yapılan çalışmalarda da bu çalışmadan elde edilen bulguyu destekler nitelikte sınıf düzeyinin artmasının daha eşitlikçi tutumlar gösterdiği görülmüştür. Atış’ın (2010) çalışmasında birinci sınıfta öğrenim gören öğrencilerin, dördüncü sınıf öğrencilerinden istatistiksel olarak daha yüksek fark bulunmuştur. Başçı ve Giray (2016) altıncı sınıf tıp fakültesi öğrencilerinin sınıf bazında en yüksek, hazırlık sınıfı öğrencilerinin sınıf bazında en düşük toplumsal cinsiyet puanlarına sahip olduğunu ve sınıf yükseldikçe toplumsal cinsiyet rollerine ilişkin tutumların olumlu yönde değiştiği ifade etmiştir. Gümüş’ün (2019) çalışmasında da benzer sonuç olarak birinci sınıf öğrencilerinin eşitlikçi cinsiyet rolü puanları, ikinci sınıf öğrencilerinin eşitlikçi cinsiyet rolü 
puanlarından düşük bulunmuştur. Birinci ve dördüncü sınıfa devam eden öğretmen adaylarının toplumsal cinsiyet rollerine ilişkin tutumları arasındaki bu farklılık üniversite yaşantısının toplumsal cinsiyet rollerine ilişkin tutumların gelişmesinde olumlu etkisinin olduğunu düşündürmektedir.

Öğretmen adaylarının TCRTÖ puanlarında üniversite eğitimine başlayıncaya kadar ikamet ettiği yere göre incelendiğinde; grupların toplumsal cinsiyete ilişkin tutumların arasında anlamlı fark gözlenmemiştir. Üniversite eğitimine başlayıncaya kadar ikamet ettiği yerin çalışmaya konu olan toplumsal cinsiyet rollerine ilişkin tutumlarının üzerinde anlamlı bir etkisinin olmadığı söylenebilir. Bu bulgu Atış’ın (2010) yaptığı çalışmada doğum yerine göre gelişmişlik düzeyine açısından farklılık görülmemiş olması, Arıcı (2011) ise öğrencilerin yaşamlarının çoğunu geçirdikleri yer ve ailelerinin yaşadıkları coğrafi bölge değişkenlerine göre farklılık olmaması, Yaşar'ın (2011) yaptığı en uzun süre yaşanılan yerleşim yerine göre anlamlı bir farklılık bulunmaması bulgularıyla örtüşmektedir. Zeyneloğlu (2008) ve Öngen ve Aytaç’ın (2013) çalışmalarında ise yaşanılan yer değişkenine göre fark bulunmuştur. Literatür incelendiğinde yaşanılan yerin büyüklüğü, kalkınmışlığı ve refah seviyesi orada yaşayan insanların toplumsal cinsiyet rolleri tutumunu etkilemekte olduğu belirtilmiştir (Güzel, 2016; Öngen ve Aytaç 2013; Zeyneloğlu, 2008) ancak yapılan çalışmalar incelendiğinde ise bu farklı1ığın her araştırmada ortaya çıkmadığı görülmektedir (Arıcı, 2011; Atış, 2010; Yaşar, 2011). Bu çalışmada ikamet edilen yer değişkenine göre fark bulunmamasının sebebi olarak çalışma grubuna dahil edilen bireylerin üniversite öğrencisi olması ve üniversite yaşantısı ile alınan eğitimin bu durumu etkilemiş olması olarak düşünülebilir.

Elde edilen bir diğer sonuç ise; anne eğitim durumu değişkenine göre öğretmen adaylarının TCRTÖ puanları arasında anlamlı fark gözlenmiştir. Yapılan analiz sonucunda bu farkın, okuryazar olmayan ile ilkokul arasında ilkokul lehine, okuryazar olmayan ile lise arasında lise lehine ve okuryazar olmayan ile üniversite mezunları arasında üniversite mezunları lehine, ortaokul ile lise mezunları arasında lise lehine, ortaokul ile üniversite mezunları arasında üniversite mezunları arasında olduğu belirlenmiştir. Bu bulgu Atış'ın (2010) ve Arıcı'nın (2011) çalışma bulgusu ile örtüşmektedir. Yaşar (2011) ve Güzel'in (2016) yaptığı çalışmada ise farklı1ık bulunmamıştır. Bu farklılık çalışma grubunda yer alan öğretmen adaylarının annelerinin toplumsal cinsiyet rollerini ne kadar benimsediği ile ilişkili olabilir. Farkın hangi gruplardan kaynaklandığı incelendiğinde anne eğitim düzeyi yüksek olan grubun TCRTÖ’ den aldığı puanın daha yüksek olduğu görülmektedir. Annenin eğitim düzeyi arttıkça toplumsal cinsiyet rollerine ilişkin tutumunun daha eşitlikçi olduğu, bu sayede çocuğunun da daha eşitlikçi bir tutuma sahip olduğu söylenebilir.

Öğretmen adaylarının TCRTÖ puanları baba eğitim durumu değişkenine göre incelendiğinde ise; grupların toplumsal cinsiyet rollerine ilişkin tutumları arasında anlamlı fark gözlenmemiştir. Baba eğitim düzeyinin öğretmen adaylarının toplumsal cinsiyet rollerine ilişkin tutumlarının üzerinde anlamlı bir etkisinin olmadığı söylenebilir. Bu çalışmadan elde edilen sonuç Zeyneloğlu (2008), Yaşar (2011) ve Başçı ve Giray’ın (2016) yaptığı çalışmalardan elde edilen sonuçlarla örtüşmektedir. 
Arıcı'nın (2011) çalışmasında ise babanın ortaokul, lise ya da üniversite eğitim düzeyinde olmasının, ilkokul eğitim düzeyinde olmasına göre daha eşitlikçi olduğu ifade edilmiştir. Çalışmalardaki farklılıklar katılımcıların babalarıyla olan ilişkilerinden kaynaklanıyor olabileceğini düşündürmektedir. Bu çalışmada anne eğitim düzeyine göre anlamlı farklılık bulunup; baba eğitim düzeyine göre bir farklılığa rastlanmamasının sebebi geleneksel aile yaşantısı içinde annenin babaya göre özellikle yaşamının ilk yıllarında çocuğun bakımını birinci sırada üstlenmesi, bununla birlikte daha fazla iletişim kurması ve etkileşim içinde olmasıyla açıklanabilir.

Çalışmadan elde edilen bulgular, TCRTÖ puanları açısından çalışmaya katılan tüm öğretmen adaylarının eşitlikçi tutuma sahip olduklarını gösterse de değişkenler açısından bakıldığında cinsiyet, sınıf ve anne eğitim düzeyi açısından fark bulunmuştur. Ele alınan cinsiyet ve sınıf değişkenleri açısından gruplar arasındaki farklılıkların azalıp; diğer gruplardaki bireylerin de daha eşitlikçi tutumlara sahip olabilmesi için üniversitelerde toplumsal cinsiyet eşitliğine yönelik seçmeli dersler programa dahil edilebilir. Ayrıca bu çalışmada ele alınan bağımsız değişkenlerin toplumsal cinsiyet rollerine ilişkin tutum üzerine etkileri ayrı ayrı incelenmiştir. Yapılacak diğer çalışmalarda değişkenlerin toplumsal cinsiyet rollerine ilişkin tutum üzerine ortak etkisine de bakılabilir.

\section{KAYNAKÇA}

Adaçay, F.R. (2014). Toplumsal cinsiyet ve kalkınma. Bursa: Ekin Yayınevi.

Akın, A \& Demirel, S. (2003). Toplumsal cinsiyet kavramı ve sağlığa etkileri. Cumhuriyet Üniversitesi Tip Fakültesi Dergisi Halk Să̆lı̆̆ Özel Eki, 25(4), 73-82.

Almutawa, F. (2005). Beliefs of pre-service teachers at the university of pittsburgh about gender roles and the role of teachers in relation to gender differences. Doctoral Dissertation. University of Pittsburgh, Pittsburgh.

Arıcı, F. (2011). Üniversite ögrrencilerinde toplumsal cinsiyet rollerine ilişsin algılar ve psikolojik iyi oluş. Yayımlanmamış Yüksek Lisans Tezi, Hacettepe Üniversitesi, Sosyal Bilimler Enstitüsü, Ankara.

Asan, H.T. (2010). Ders kitaplarında cinsiyetçilik ve öğretmenlerin cinsiyetçilik algılarının saptanması. Fe Dergi: Feminist Eleştiri, 2(2), 65-74.

Atış, F. (2010). Ebelik/ hemşirelik 1. ve 4. slnıf öğrencilerinin toplumsal cinsiyet rollerine ilişkin tutumlarının belirlenmesi. Yayımlanmamış Yüksek Lisans Tezi, Çukurova Üniversitesi Sağlık Bilimleri Enstitüsü, Adana.

Bar-Tal, D. \& Harel, A. S. (2002). Teachers as agents of political influence in the Israeli high schools. Teaching and Teacher Education, 18(1), 121-134.

Başcı, B. \& Giray, S. (2016). Üniversite öğrencilerinin toplumsal cinsiyet rollerine ilişkin tutumlarının çok değişkenli istatistiksel tekniklerle analizi. Journal of Life Economics, 3(4), 117-142.

Bem S. L. (1981). Gender schema theory: a cognitive account of sex typying, Psychologial Review, 88(4), 354-364.

Büyüköztürk Ş., Kılıç Çakmak, E., Akgün Ö.E., Karadeniz Ş. \& Demirel F. (2016). Bilimsel araştırma yöntemleri (22. baskı). Ankara: Pegem Akademi Yayınc1l1k. 
Can, G. (2013). Kişilik gelişimi (Psikosoyal ve ahlak gelişimi). B. Yeşilyaprak. (Ed)., Eğitim psikolojisi içinde (125-163) (10.bask1). Ankara: Pegem Akademi Yayıncılık.

Çatalcalı-Soyer, A. (2009). Okul öncesi dönem çocuk hikâye kitapları: Stereotipler ve kimlikler. Mehmet Akif Ersoy Üniversitesi Sosyal Bilimler Enstitüsü Dergisi,1 (1), 13-27.

Doyle, J. A. \& Paludi, M. (1998). Sex and gender: The human experience. Boston: McGraw Hill.

Dökmen, Z.Y. (2015). Toplumsal cinsiyet sosyal psikolojik açıklamalar. İstanbul: Remzi Kitapevi.

Ecevit, Y. (2016). Toplumsal cinsiyet sosyolojisine başlangıç. Y.Ecevit \& N.Karkıner (Editörler)., Toplumsal cinsiyet sosyolojisi içinde (2-29) (5.bask1). Eskişehir: Anadolu Üniversitesi Açıöŏgretim Fakültesi Yayını

Engin-Demir, C., Kılı̨̧ A.Z., Çalışkan, B., Hanbay-Çakır, E. Karaman-Güney, N. \& Şener- Özbek, Ü. (2016). Okulların toplumsal cinsiyete duyarlılık açısından değerlendirilmesi- Başlangıç durum değerlendirmesi ve ihtiyaç analizi raporu. https://www.researchgate.net/publication/301621171_Okullarin_Toplumsal_Cinsiyete_Duyarlilik_A cisindan_Degerlendirilmesi_-_Baslangic_Durum_Degerlendirmesi_ve_Ihtiyac_Analizi_Raporu [Erişim Tarihi: 29.06.2020]

Ergün, M. (1994). Eğitim ve toplum (Eğitim sosyolojisine giriş). Ankara: Ocak Yayınları.

Gunderson, E.A, Ramirez, G., Levine, S.C. \& Beilock, S.L. (2012). The role of parents and teachers in development of gender-related math attitudes. Sex Roles, 66(3-4), 153-166.

Gümüş, Z. (2019). Üniversite öğrencilerinin toplumsal cinsiyet rollerine ilişkin tutumlarının belirlenmesi. Türkiye Bütüncül Psikoterapi Dergisi, 2(3), 31-47.

Gündüz-Kalan, Ö. (2010). Reklamda çocuğun toplumsal cinsiyet teorisi bağlamında konumlandırılış1: Kinder reklam filmleri üzerine bir inceleme. İstanbul Üniversitesi İletişim Fakültesi Dergisi, 1(38), 75-89.

Gündüz-Şentürk, S. (2015). Okul öncesi dönem çocukları için basılan resimli öykü kitaplarının toplumsal cinsiyete ilişkin kalipyargılar yönünden incelenmesi, Yayımlanmamış Yüksek Lisans Tezi, Ege Üniversitesi Sosyal Bilimler Enstitüsü, İzmir.

Güzel, A. (2016). Öğrencilerin toplumsal cinsiyet rolleri tutumları ve ilişkili faktörler. Gümüşhane Üniversitesi Sağllk Bilimleri Dergisi, 5(4), 1-11.

Helgeson, V.S. (2012). The psychology of gender (4th ed.). New Jersey: Pearson Education.

Kalaycı, N. (2015). Toplumsal cinsiyet eşitliği açısından bir çizgi film çözümlemesi: Pepee. Ĕ̌itim ve Bilim, 40 (177), 243-270.

Kimmel, M. S. (2000). The gendered society. New York: Oxford University Press.

Köseler, F. (2009). Okul öncesi öykü ve masal kitaplarında toplumsal cinsiyet olgusu. Yayımlanmamı̧̧ Yüksek Lisans Tezi, Adnan Menderes Üniversitesi Sosyal Bilimler Enstitüsü, Aydın.

Lahelma, E. (2006). Gender perspective: A challenge for schools and teacher education, Jakku-Sihonen, R. \& Niemi, H. (Eds.) In Research-based Teacher Education in Finland - Reflections by Finnish Teacher Educators (203-213). Turku: Finnish Educational Research Association.

Ocak- Karabay, Ş., Güzeldere- Aydın, D., Tunç, M. \& Kanbur, B. N. (2019). The effects of social gender equality-oriented educational activities and materials on gender stereotypes of children. International Journal of Educational Research Review, 4(3), 275-287. 
Oğuz- Rollas, B. (2017). 0-6 yaş resimli çocuk hikâye kitaplarında toplumsal cinsiyet inşası. Yayımlanmamış Yüksek Lisans Tezi, Yaşar Üniversitesi Sosyal Bilimler Enstitüsü, İzmir.

Öngen, B. \& Aytaç, S. (2013). Üniversite öğrencilerinin toplumsal cinsiyet rollerine ilişkin tutumları ve yaşam değerleri ilişkisi. Sosyoloji Konferansları, 42(2), 1-18.

Öztürk, H. (1993). Eğitim Sosyolojisi. Ankara: Hatiboğlu Yayınları.

Pomerleau, A., Bolduc, D., Malcuit, G., \& Cossette, L. (1990). Pink or blue: Environmental gender stereotypes in the first two years of life. Sex Roles, 22, 359-367

Ryle, R. (2012). Questioning gender (A sociological exploration). London: Sage Publications.

Schechter, K. (2013). Gender equity in education: meanings and practices. Unpublished Master's Thesis, Universtiy of Pittsburgh, Pittsburgh.

Seçgin, F. \& Tural, A. (2011). Sınıf öğretmenliği bölümü öğretmen adaylarının toplumsal cinsiyet rollerine ilişkin tutumları. Education Sciences, 6(4), 2446-2458.

Stoll, L. C. (2011). Teachers' perspectives on race and gender: Strategic intersectionality and the countervailing effects of privilege, Unpublished Doctoral Dissertation, Loyola University, Chicago.

Tatar, M. \& Emmanuel, G. (2010) Teachers' perceptions of their students' gender roles, The Journal of Educational Research, 94(4), 215-224

Torgrimson, B.N \& Minson, C.T. (2005). Sex and gender: what is the difference? Journal of Applied Phsiology, 99, 785-787.

Vefikuluçay, D., Zeyneloğlu S, Eroğlu, K. \& Taşkın, L (2007). Kafkas Üniversitesi son sınıf öğrencilerinin toplumsal cinsiyet rollerine ilişkin bakış açıları. Hacettepe Üniversitesi Hemşirelik Fakültesi Dergisi, 14(2), 26-38.

Yaşar, B. (2011). Öğretmen adaylarının toplumsal cinsiyet rolleri tutumlarının kadın sağlı̆̆ hemşireliği açısından değerlendirilmesi. Yayımlanmamış Yüksek Lisans Tezi, Mersin Üniversitesi Sağlık Bilimleri Enstitüsü, Mersin.

Wolter, I., Braun, E., \& Hannover, B. (2015). Reading is for girls!? The negative impact of preschool teachers' traditional gender role attitudes on boys' reading related motivation and skills. Frontiers in Psychology, 6, 1-11.

Zeyneloğlu, S. (2008). Ankara'da hemşirelik öğrenimi gören üniversite öğrencilerinin toplumsal cinsiyet rollerine ilişkin tutumları. Yayımlanmamış Doktora Tezi, Hacettepe Üniversitesi Sağlık Bilimleri Enstitüsü, Ankara.

Zeyneloğlu, S. \& Terzioğlu, F. (2011). Toplumsal cinsiyet rolleri tutum ölçeğinin geliştirilmesi ve psikometrik özellikleri. Hacettepe Üniversitesi Eğitim Fakültesi Dergisi, 40, 409-420. 


\section{EXTENDED ABSTRACT}

It is clear that sex is an important variable to be considered in all basic physiological and biological studies. The concept of sex in medical sciences is called as 'sextinked inheritance' or 'sex' in biology. From this aspect, sex is a feature that is inborn and identical everywhere In addition to the biological characteristics of being a woman or a man, being a member of a society has a social meaning shaped by many values such as morality, religion, culture, and tradition. This social meaning appears as gender. In other words, gender is a feature and expectations shaped, constructed and imposed by society as well as the biological sex of the individual.

There are theories such as psychoanalytic theory, social learning theory, cognitive development theory, gender schema, which explain gender. When the literature is examined, it is seen that factors such as family, sibling and friend groups, children's books, mass media, school, and teachers affect gender development. When we look at the researches about what gender is, how it occurs and what it is affected by, it is seen that it is desired to adopt an equalitarian approach. Socialization process is effective in forming attitudes towards gender roles. In this process, the environment of the individual is an important variable. Considering preschool period includes many critical stages, it is seen how important to determine the attitude of pre-school teacher candidates. Since they interact with the children, it is important what kind of attitude preschool teacher candidates have. In accordance with this importance, the purpose of the study is to determine the attitudes of pre-school teacher candidates relating to gender roles. In the direction of this purpose, relationship between pre-school teacher candidates' attitudes relating to gender roles and various variables such as sex, class, development level of the place where she/he lived until the beginning of university education, education level of the parents was examined. This study has been conducted to determine the attitudes of pre-school teacher candidates towards gender roles.

This study was carried out by scanning method. This study was conducted with 165 first and fourth-grade preschool teacher candidates who were selected by stratified purposive sampling method among the students at Aydin Adnan Menderes University Faculty of Education, Preschool Education Department. In this research, "Gender Role Attitude Scale" developed by Zeyneloğu (2008) was used as the data collection tool. The data obtained from the study were evaluated in the appropriate computer program. In this study, sociodemographic characteristics of teacher candidates constitute independent variables while gender roles attitude scale scores constitute dependent variables. For the significance level of the statistical tests $\mathrm{p}<0,05$ was accepted. Kolmogorov-Smirnov tests, descriptive statistics, Mann-Whitney U and Kruskal-Wallis tests were used to analyze the data.

As a result of the tests conducted, according to sex variable $(z=-4,425, p<0,05)$, according to be a teacher candidate from first grade or fourth grade $(z=-3,727, p<0,05)$, according to the mother's education level variable $\left[\mathrm{X}^{2}(6)=19,020, \mathrm{p}<, 05\right]$ significant differences were found. There was no 
significant difference found according to the variable of the place where participants lived until the beginning of university education $\left[\mathrm{X}^{2}(2)=3,909, \mathrm{p}>0,05\right]$ and according to the father's education level variable $\left[X^{2}(6)=9,482, p>0,05\right]$. In universities, elective courses on gender equality may be included in the program to decrease the differences between the groups in terms of gender and class variables. Also, these courses may be useful to enable individuals in other groups to adopt more egalitarian attitudes. On the other hand, the effects of independent variables discussed in this study on attitude towards gender roles were examined separately. In future studies, the common effect of variables on attitude towards gender roles may also be examined. 